\title{
The effect of temperature cycling on the DC conductivity of polyethylene
}

\author{
Khalil, M.S.; Henriksen, Mogens; Henk, Peter O
}

Published in:

Proceedings of the 4th International Conference on Conduction and Breakdown in Solid Dielectrics

Link to article, DOI:

10.1109/ICSD.1992.224962

Publication date:

1992

Document Version

Publisher's PDF, also known as Version of record

Link back to DTU Orbit

Citation (APA):

Khalil, M. S., Henriksen, M., \& Henk, P. O. (1992). The effect of temperature cycling on the DC conductivity of polyethylene. In Proceedings of the 4th International Conference on Conduction and Breakdown in Solid Dielectrics (pp. 67-71). IEEE. https://doi.org/10.1109/ICSD.1992.224962

\section{General rights}

Copyright and moral rights for the publications made accessible in the public portal are retained by the authors and/or other copyright owners and it is a condition of accessing publications that users recognise and abide by the legal requirements associated with these rights.

- Users may download and print one copy of any publication from the public portal for the purpose of private study or research.

- You may not further distribute the material or use it for any profit-making activity or commercial gain

- You may freely distribute the URL identifying the publication in the public portal 
THE EFTECT OP TEMPERATURE CYCLING

ON THE D.C. CONDUCTIVITY OF POLYETHYLENE

M. Balah Thalil, M. Henriksen and P.O. Henk

\section{ABsmRACT}

The effect of temperature cycling between $40^{\circ} \mathrm{C}$ and $80^{\circ} \mathrm{C}$ during a conditioning procedure of combined temperature and electric field on the d.c. conductivity of LDPE has been studied, and compared with d.c. conductivity results using a constant temperature of $80^{\circ} \mathrm{C}$ and an identical sample at the same experimental conditions.

Results indicate that the drop in the current level at $80^{\circ} \mathrm{C}$ after ten days of conditioning is lower in the thermally cycled sample than the corresponding drop in the sample subjected to constant temperature. The difference is attributed to the different morphological changes in each sample due to the difference of the thermal profile in each case.

\section{INTRODUCTION.}

The electrical conductivity of polymers has been studied by many authors and a large number of references can be found in the literature [ Lewis [1], Fischer [2], and Kryszewski [3] and references therein]. However, no unified picture of electrical conduction in polymers exists as yet. One reason behind this state of affairs can be the dependence of the d.c. conductivity of of affairs can be the dependence of the d.c. conductivity of insufficiently investigated. Polymer structural characteristics are known to be some of these factors, which have a detrimental effect on the electrical conduction of polymeric materials. Such characteristics are in their turn, very sensitive to the various mechanical and thermal treatments to which the polymer is subjected during the different manufacturing processes and service conditions. Thermal cycling is a characteristic of HVDC cable insulation operation.

In the present work, the effect of combined electric field and temperature on the d.c. conductivity of LDPE was studied using thick samples and two different thermal profiles.

EXPERIKENTAL.

Test samples were discs of $175 \mathrm{~mm}$ diameter and about $1.8 \mathrm{~mm}$ thick -

M.S. Khalil is with the Danish Electrical Research Institute (DELRI), Lyngby, Denmark.

M. Henriksen and P.O. Henk are with the department of Electric Power Engineering, Technical University of Denmark.

O-7803-0129-3/92 \$3.00 1992 IEEE 
prepared by pressing from pellets. Gold circular electrodes and guard rings were provided by vacuum evaporation. The material used was LDPE (density $0.922 \mathrm{gm} / \mathrm{cm}^{3}$; melt index $1.85 \mathrm{gm} / 10 \mathrm{~min}$ ). The test samples were identical and taken from the same batch. Moreover, DSC measurements were made on pieces of each sample before subjecting the samples for any electrical or thermal treatment. The samples proved to have a similar degree of crystallinity.

The set-up shown in Fig. 1 is a modified version of the system described elsewhere Henriksen et.al. [4]. The main advantage of the present system is that it allows for the simultaneous investigation of two samples under the same experimental conditions as well as the possibility of using two different thermal profiles while keeping the other experimental conditions identical. In the present investigation, the samples were identical, and two different thermal profiles were used, sample no. 1 was subjected to constant temperature of $80^{\circ} \mathrm{C}$. while sample no. 2, was subjected to thermal cycling between $80^{\circ} \mathrm{C}$ and $40^{\circ} \mathrm{C}$.

A highly stable voltage of $50 \mathrm{kV}$ d.c. was applied across the two samples for 10 days, while the current flowing in each sample was monitored.

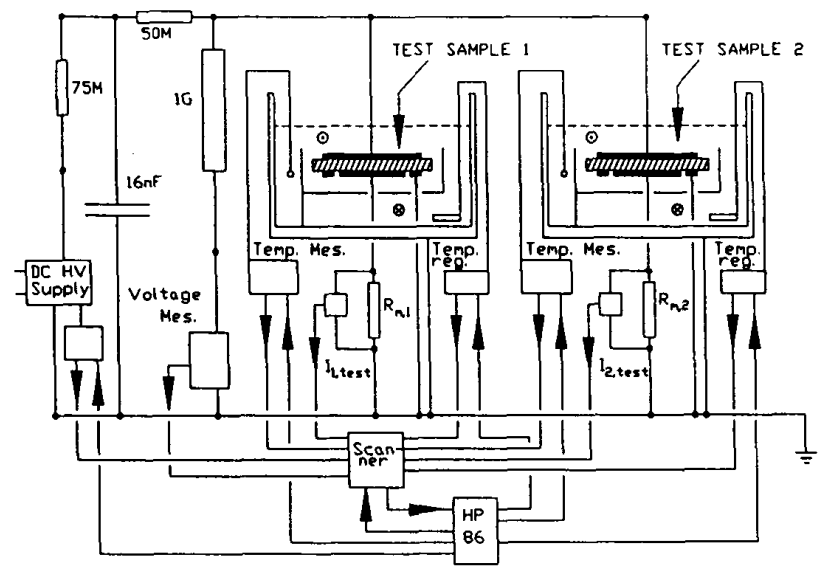

Pigure 1 Test set-up.

REBULTS ANP DIBCUBSION.

In Fig. 2 (a) is shown the current-time dependency for sample no. 1, which was subjected to thermal profile 1 with constant temperature
of $80^{\circ}$ (insert). In this case the current has decayed from $70 \mathrm{nA}$ to a quasi steady state of about $4.4 \mathrm{nA}$ after about 8 days. (The total drop of the current is about $94 \%$ of the maximum initial value). 


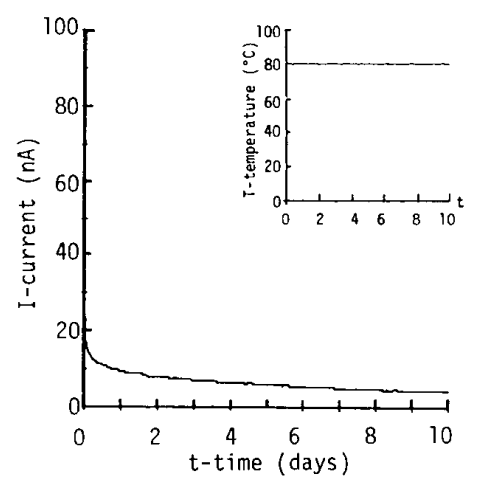

(a)

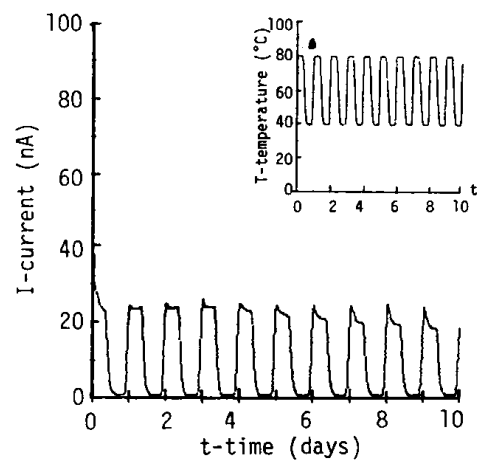

(b)

Fig. 2 The current time dependencies for:

(a) sample no. 1, (b) sample no. 2. (Inserts are

the corresponding thermal profiles).

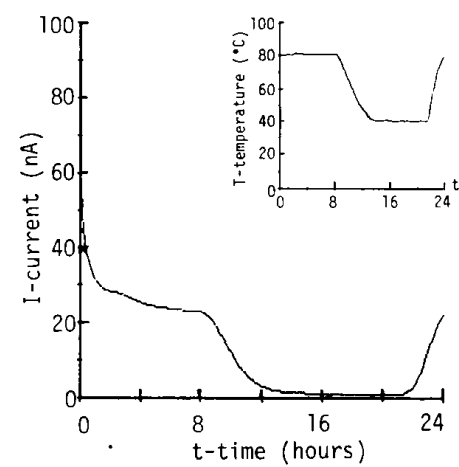

(a)

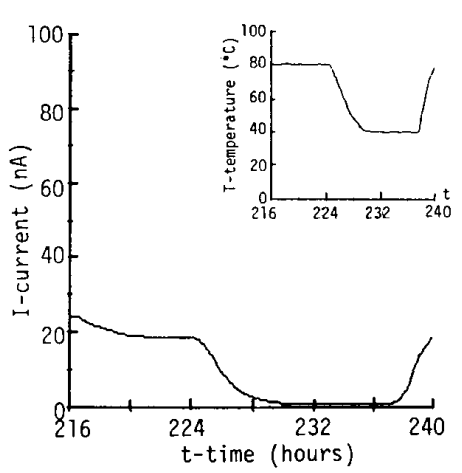

(b)

Fig. 3 The current-time dependencies for

sample no. 2 . (a) puring the first thermal cycle,

(b) During the last thernal cycle. (Inserts

are the corresponding thermal profiles). 
In Fig. 2 (b) is shown the current-time dependency for sample no. 2, where the sample was thermally cycled between $80^{\circ} \mathrm{C}$ and $40^{\circ} \mathrm{C}$ (insert). In Fig. 3(a, b) are shown the current-time dependencies as well as the temperature profiles (inserts) for sample no. 2 during the 24 hours of the first and the last cycling periods respectively. In this case, the minimum current level at $80^{\circ} \mathrm{C}$ during the last cycle is $20 \mathrm{nA}$ giving a total drop of 798 if compared to the corresponding value during the first cycle. Moreover, the current is decaying with a decreasing rate from cycle to cycle. In the period of constant high temperature of the thermal cycle $\left(80^{\circ} \mathrm{C}-8\right.$ hours $)$ the total drop of the current in the first cycle $\Delta I / I_{\max }=79 \%$ while the corresponding value is the last cycle is $17 \%$.

The electric current flowing in an insulator after application of voltage step has been explained as a result of charge carrier injection in the insulator from the electrodes and the build up of trapped space charge, wintle [5]. Current-voltage characteristics measured on PE films are consistent with space charge limited conduction in this material.

Any changes in the morphology and/or the crystalline structure of the material by heat treatment may lead to change of the energy, density and distribution of trap levels resulting in the change of its d.c. conductivity.

The dependence of d.c. conduction on the crystallinity and morphology of polymeric materials, has been reported by several authors Sazhin et.al. [6], Kargin et.al. [7] and Amborski [8].

The present results seem to coincide with the above picture. For the two samples, charge carriers are injected at the electrodes under the effect of the electric field, leading to space charge formation which controls the current flow in each sample. For sample no. 1 , the material is subjected to a constant temperature of $80^{\circ} \mathrm{C}$ during the whole period of conditioning. For sample no. 2 , the material is subjected to a different thermal profile (cycling between $80^{\circ} \mathrm{C}$ and $40^{\circ} \mathrm{C}$ ). Since the two samples are subjected to two different thermal profiles, the resulting structural changes are expected to be different in each sample giving rise to the observed different conductivities.

\section{CONCLUBIONB AND RECONRENDATIONS}

In a process of combined thermal and electrical conditioning of polyethylene; thermal cycling between $80^{\circ} \mathrm{C}$ and $40^{\circ} \mathrm{C}$ leads to a higher d.c. conductivity level than the thermal conditioning at constant temperature of $80^{\circ} \mathrm{C}$. One reason behind this state of affairs can be the different structural changes which occur in the material under the different structural changes
the different thermal profiles.

Further work should be done to establish the correlation between the electrical and structural properties of polyethylene.

\section{MCENOWHDEBKRETS}

The authors are grateful to NKT ENGINEERING, ELSAM and ELKRAFT for their support of the present work. 


\section{LIBT OF REEBRENCES}

1. Lewis, T.J., 1976, CEIDP Annul. Report, 533-561.

2. Fischer, P., 1977/1978, J. Electrostatics, 4, 141-173.

3. Kryszewski, M., 1975, J. Polymer science symposium, 50, 359-404.

4. Henriksen, M., Larsen, E., Johannesson, H.S., 1987, CEIDP Annul. Report., 375-381.

5. Wintle, H.J., 1974, J. Non-Crystalline Solids, 15, 471486.

6. Sazhin, B.I. and Podosenova, N.G., 1964, Polym. Sci. (USSR), $6,162-169$.

7. Kargin, V.A., Podosenova, N.G., Adrianova, G.P. and Sazhin, B.I., 1967, polym. Sci. (USSR), 9, 323-328.

8. Amborski, L.E., 1962, J. Polymer Science, 62, 331-346. 